
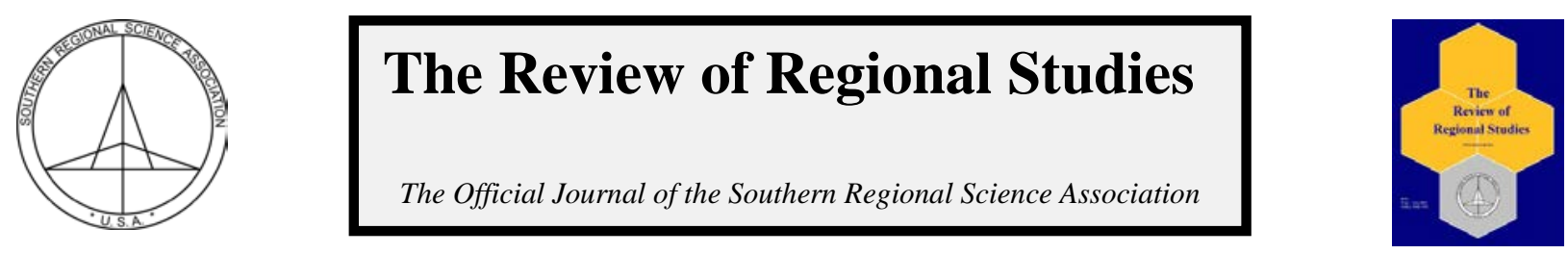

\title{
Regionalization and Consolidation of Municipal Taxes and Services*
}

\author{
Joshua C. Hall, Josh Matti, and Yang Zhou \\ Department of Economics, West Virginia University, USA
}

\begin{abstract}
The United States has a rich history of local government taxation and good provision. The last fifty years, however, have seen increasing calls for the regionalization of municipal taxes and services from policymakers. Arguments for greater regionalization emphasize improved efficiency, enhanced equity, mitigation of spillovers, and improved economic development. A number of localist scholars have responded to regionalists' concerns. This review articulates regionalists' arguments, the localists' response, and summarizes the relevant empirical literature to see which side's theories hold forth in the data.
\end{abstract}

Keywords: local governments, Bloomington School, regionalism, localism

JEL Codes: H11, H70, H71, H77

\section{INTRODUCTION}

The U.S. has a rich history of local governments. However, in the last century there have been several movements pushing for local government consolidation into regional forms of government (Wheeler, 2002). Early arguments for reform such as those advanced by Maxey (1922) focus on the unnecessary complexities of a fragmented system. In recent decades, arguments for consolidation have broadened to include the economies of scale and scope enjoyed by larger governments, fragmentation as institutionalizing segregation by race and wealth, and regional environmental concerns. Most recently, in the wake of the Great Recession, consolidation pressures have focused on achieving efficiencies in local government operations as a way of dealing with stagnant local property tax revenues. The push for more streamlined government coming out of the Great Recession continues today in states such as Illinois. In 2011, Illinois created the Local Government Consolidation Committee and in 2015 the newly created Task Force on Local Government Consolidation issued a 406 page report on how to consolidate Illinois' roughly 7,000 governments (Craver, 2016). Although spanning a century and voiced by a variety of authors, the arguments for consolidation center upon efficiency, equity, spillovers, and development.

Starting with the Bloomington School of political economy (Ostrom, Tiebout, and Warren, 1961; Ostrom, 1972) but bringing together many areas in public economics and regional

\footnotetext{
* We would like to thank two anonymous referees for their valuable comments and advice. We would also like to thank the seminar participants at West Virginia University and Institute for Humane Studies for their helpful comments. We are also thankful for comments at the 2016 International Conference of Prices \& Markets in Toronto, Canada. Joshua C. Hall is Associate Professor of Economics and Director of the Center for Free Enterprise in the College of Business and Economics at West Virginia University, Morgantown, WV 26506. Josh Matti and Yang Zhou are Economics Ph.D. Candidates in the Department of Economics at West Virginia University. Corresponding Author: Joshua C. Hall E-mail:joshua.hall@mail.wvu.edu
}

(c) Southern Regional Science Association 2018.

ISSN 1553-0892, 0048-749X (online)

www.srsa.org/rrs 
science, localists have responded to each of the regionalists' concerns. In terms of efficiency, they highlight the cost-reducing competition associated with fragmentation, preference revelation and matching at the local level, and inefficiencies inherent in larger governments. With equity, they argue that consolidation does not guarantee greater equity and that other means besides consolidation exist for solving equity problems. In dealing with spillovers, localists emphasize voluntary cooperation among jurisdictions and the inability of consolidated governments to account for the unique spillovers of each public good. In responding to development arguments, localists point to the lack of real-world evidence for consolidated governments growing faster.

While the literature has primarily developed in the public administration and public economics fields, there are key regional dimensions. Local governments are spread spatially across regions and are related to the kinds of variables regional scientists study. Central topics in regional science such as migration, policy diffusion, regional economic specialization, regional economic growth, and zoning are likely influenced by the institutional environments of local governments. However, exploring the relationship between local government structure and key regional topics remains an underdeveloped literature.

One area where a connection has been made between local governments and regional science is with local government borders. Hall (2015, 2017) finds that greater congruence between school districts and local municipalities' boundaries is associated with greater local spending on schools and higher housing prices. Since there is a natural connection between regional science and local/regional governments given that both entail activity over a defined geographic space, research that better integrates regionalist government research from political science, economics, and public administration will improve regional scientists analysis of policy. This paper is a survey of the literature on the regionalization of local governments meant to inform regional scientists of the literature so that subsequent research on the regionalization of local governments incorporates the topics and tools of regional science.

The rest of the paper proceeds as follows. Section 2 summarizes the theoretical ${ }^{1}$ arguments of the regionalists and localists. Section 3 draws upon numerous case studies to illustrate how localists' theoretical considerations function in the real world. Section 4 concludes and emphasizes how regional science can contribute to the local government regionalization literature.

\section{THEORY}

While the debate between regionalists and localists over the most appropriate structure of local government has been active for the last century, the arguments tend to fall into one of four categories: efficiency, equity, spillovers, and development. ${ }^{2}$ Each side has a fully developed theoretical perspective for efficiency, equity, and spillovers while theoretical arguments for development lag behind.

\section{$2.1 \quad$ Efficiency}

The efficiency argument for consolidation rests upon economies of scale, economies of scope, and the inefficiencies of special districts. Smaller governments in a fragmented system are

\footnotetext{
${ }^{1}$ For recent surveys of the empirical literature see Yeung (2009), Jimenez and Hendrick (2010), and Kim and Jurey (2013).

2 This section is organized by ideas rather than by authors. Given that authors sometimes develop the opposing arguments before asserting their own argument by way of critique, some authors are cited in both the regionalists and localists sub-sections. For example, Ostrom (1972) with economies of scale.
}

(C) Southern Regional Science Association 2018. 
not able to take advantage of the lower per unit costs of providing services that are associated with economies of scale. In capital intensive services such as power, sewage, and public transportation, governments can take advantage of economies of scale by spreading the high fixed cost of capital across a larger number of citizens (Ostrom, 1972). Additionally, more consolidated governments achieve lower costs through eliminating administrative duplication (Adams, 1965) or from lower input prices as a result of greater purchasing power (Boyne, 1992). In addition to economies of scale, consolidated governments also achieve economies of scope where the cost of providing a diversified set of services by a single government is less than the cost of specialized governments providing the same services (Grosskopf and Yaisawarng, 1990). The cost savings of economies of scope are typically achieved through sharing inputs in the production of similar services such as police and fire departments sharing central dispatchers (Grosskopf and Yaisawarng, 1990).

While regionalists use economies of scale and scope to demonstrate the efficiency of larger governments, they also point out that the most common form of fragmentation can result in higher costs. Ninety-six percent of the 8,141 new governments created in the U.S. between 1987 and 2007 were special districts (Jimenez and Hendrick, 2010). Eberts and Gronberg (1988) and Berry (2008) argue that special districts such as public utilities, police protection, and most prominently, school districts are not subject to the same level of horizontal competition as general purpose governments. These authors contend that general purpose governments provide similar services and compete for residents while special districts offer different services and share the same jurisdiction.

Special districts with a single function are not subject to the threat of citizen migration in the same way as multi-purpose governments because the costs of moving are high relative to the benefits of a single improved service (Boyne, 1992). With less horizontal competition, the most common types of government in a fragmented system have less of an incentive to keep costs down. Additionally, Berry (2008) argues that special districts have less political visibility and are controlled by interest groups ${ }^{3}$ that focus on influencing the most relevant single-purpose government. With concentrated benefits for interest groups and the costs of taxation diffused over all groups, a fiscal common-pool problem similar to the 'overfishing' problem emerges (Berry, 2008). Lastly, special districts which are well-suited for providing services with economies of scale, will have higher costs with higher levels of fragmentation (Zax, 1989; Boyne, 1992). ${ }^{4}$ In the regionalists' view, consolidated governments are able to avoid the adverse incentives of special districts and take advantage of economies of scale and scope.

Localists have compiled a voluminous literature on the efficiency gains from fragmentation by countering the claims of regionalists and by broadening the concept of efficiency. Although there may be economies of scope for regional governments, providing many services in a single organization makes it difficult to discern the costs and benefits of any single service (Boyne, 1997). With less public scrutiny over specific costs and benefits of services, government functions providing those services face less of an incentive to economize on costs (Boyne, 1992; 1997).

\footnotetext{
${ }^{3}$ For example, teachers are two to seven times more likely to vote in California school district elections than other registered voters (Moe, 2006).

${ }^{4}$ Overlapping jurisdictions such as county and state police face many of the same issues as special districts. Higher costs result as citizens view their services as mutually enhancing rather than redundant and as complements rather than substitutes (Turnbull and Djoundourian, 1993; Campbell, 2004).
}

(C) Southern Regional Science Association 2018. 
Although regional governments may have economies of scale, larger governments can have higher costs. As the geographic area of a jurisdiction increases, so does the cost of delivering services to outer, more remote regions (Boyne, 1992). Administrative costs can also increase as a more complex, hierarchical structure leads to 'bureaucratic congestion' (Ostrom, Tiebout, and Warren, 1961; Boyne, 1992). Additionally, consolidated local governments exhibit greater monopoly power. Just as monopolies in the marketplace are associated with higher prices and lower quality products, government monopolies tend to have higher costs and lower quality services (Bish and Warren, 1972). Economies of scale also vary based upon the service (Ostrom, 1972). With different average unit costs for different services, a single government cannot operate at the minimum average unit cost for each service. By recognizing that there are different kinds of public goods with different appropriate levels of management (Ostrom, Tiebout, and Warren, 1961; Bish and Warren, 1972), fragmented single-purpose governments of different sizes can provide their services at their unique, most efficient level of production. One way of achieving this end is through the creation of special districts, which as localists argue, are not necessarily associated with higher costs.

Although special districts may not face significant competition from citizens relocating to another district (Boyne, 1992), there are other incentives to keep costs low. In the absence of exit, citizens can still exercise their voice by communicating complaints and proposing alternatives (Hirschman, 1970). As the fragmentation of special districts increases, citizens are better able to voice their grievances through 'yardstick competition’ (Besley and Case, 1995). Citizens can compare the performance of similar jurisdictions and reward or punish politicians in their jurisdiction (Salmon, 1987). If a special district is underperforming relative to similar districts in other areas, then citizens can punish the politicians in charge by voting them out of office. The indirect competitive pressure from other similar districts keeps costs down.

The localists' focus on competition, not just with special districts but with all forms of local governments, comprise a set of arguments that extend beyond economies of scale, economies of scope, and the special issues of special districts. Tiebout (1956) is the foundational local government competition model. In a system of decentralized local governments, if citizens are unsatisfied with the tax and service mixture provided in their jurisdiction, they can 'vote with their feet' by moving to another jurisdiction. ${ }^{5}$ With fragmentation, the competitive pressure is heightened since with larger jurisdictions, moving away from jobs and social circles can be prohibitively costly (Zax, 1989). If there is fragmentation, local governments face competitive pressure to provide an efficient mixture of taxes and services in order to maintain or attract residents. This competition among local governments is crucial for overcoming the budgetmaximizing behavior of bureaucrats (Niskanen, 1975) that contributes to a continually growing, revenue-maximizing Leviathan government (Brennan and Buchanan, 1980). With fragmentation, it is difficult for a government to generate a large revenue through high taxes.

A final efficiency argument from the localists comes from viewing efficiency not merely as minimizing costs, but also as outcomes matching citizens' preferences. Local governments provide public goods, which have long been known to suffer from a preference revealing problem as people do not reveal their preferences as in market purchases (Samuelson, 1954). An often overlooked aspect of the Tiebout model (1956) is that it is framed as a way of overcoming

\footnotetext{
${ }^{5}$ Additionally, as pointed out by an anonymous referee, a government's mixture of taxes and services not only affects migration out of an area but also willingness to migrate into an area.
}

(C) Southern Regional Science Association 2018. 
the preference revealing problem of public goods. Moving or not moving acts as a market-like test that reveals an individual's actual demand for public goods. With more local governments comes a greater variety of public goods provision that enables residents to reveal and enjoy their desired combination of taxes and services. As outlined in Oates' decentralization theorem (Oates, 1972; 2005), a greater variety of local public goods can improve social welfare. In this theorem, local governments providing varied levels of public goods in line with heterogeneous local preferences leads to a higher level of social welfare than a central government providing a uniform level of public goods across all jurisdictions.

Additionally, once residents are located within smaller jurisdictions the incentives of politicians and citizens align to maintain public goods provision that matches preferences. Although citizens have limited knowledge about regional issues, they are better informed about local issues and more easily access points of contacts to voice their concerns about local issues (Ostrom, Tiebout, and Warren, 1961). With fragmented governments providing specific services that citizens are informed about, citizens are able to precisely express their preferences for any single service (Bish and Warren, 1972). However, with a single government there is 'full line forcing' where citizens pay one fee for a bundle of services, regardless of how they value each individual service (Boyne, 1992; 1997). Centralized governments also encourage special projects because of concentrated benefits and dispersed costs (McKean, 1964; Giertz, 1981). The benefits of a special project are enjoyed by a local area while the costs are spread across all citizens living within the jurisdictional boundaries of the centralized government. However, with fragmented local governments, local residents bear the full burden of the costs, and therefore, more accurately express their true preference for public goods.

\subsection{Equity}

Although efficiency arguments have been the primary focus of debates between regionalists and localists, equity concerns have been increasingly common in the last half century. The fundamental assertion of the regionalists is expressed in the social stratificationgovernment inequality thesis (SSGI). Introduced by Hill (1974), the SSGI argues that local government fragmentation is an institutional way of promoting racial segregation and wealth inequality. Local governments use zoning laws such as restrictive covenants to create enclaves of wealthy, racially homogenous communities. While wealthy, white, and often suburban communities seek to shelter themselves from 'undesirable demographics,' pockets of poverty emerge in minority jurisdictions. A mismatch is created where jurisdictions with the greatest need for resources have the lowest ability for generating revenue. Fragmentation is not just a tool used to institutionally create racial segregation and wealth inequality, but it also acts to reinforce preferences for separation. With greater institutional separation along racial and wealth lines, trust and sympathy among different racial and wealth classes declines, which leads to increased efforts to formally fragment society into local jurisdictions (Lowery, 2000).

Regionalists do not view the often market-oriented solutions of the localists to be helpful in solving equity problems. Indeed, they are seen as a primary cause. Williams (1967) contends that individuals have certain lifestyle preferences and values that divide people into different social worlds. Within the context of the Tiebout (1956) model, sorting into different jurisdictions is driven less by service preferences and more by maintaining lifestyles (Lowery, 2000). The result is racial segregation and wealth inequality. The Tiebout (1956) model can also be used to explain an under-provision of redistributive services in poor jurisdictions. The most mobile sources of tax revenue that jurisdictions compete for are high-income residents and businesses, 
both of which avoid the higher taxes necessary for redistributive services (Hall, 2006; Hall and Ross, 2010). In competing for mobile sources of tax revenue, jurisdictions underprovide redistributive services that poor households demand (Jimenez, 2014).

When the Tiebout (1956) mechanism functions, it can have adverse effects for poor residents, but when it fails to function, the results can be even less equitable. In the standard Tiebout (1956) model, governments faced with the threat of citizens relocating will find a way to provide services more efficiently. However, another possibility is that the exit of businesses and wealthy households leaves behind a jurisdiction with limited revenue to provide even the most basic services (Howell-Moroney, 2008). In the regionalists' view, consolidated governments overcome the equity problems of fragmentation by drawing people out of their segregated enclaves into a more unified, equitable jurisdiction.

Localists' equity defense for fragmentation includes three main points. First, there is no guarantee that political consolidation leads to greater equity. Minority voting strength can be diminished through the process of consolidation. Once merged with other districts, racially minority jurisdictions formerly with minority representatives may not represent a large enough percentage of the population to influence the outcome of elections, and thus, lose their minority representation (Zimmerman, 1970). With less political influence, instead of being the recipients of redistribution, poor and racially minority residents can actually experience their limited tax base used to finance projects benefitting wealthier, more politically powerful residents (Parks and Oakerson, 2000). For localists, equity is weakened in consolidated jurisdictions because poor and minority residents lose the voice and political control they enjoy in smaller jurisdictions.

While smaller jurisdictions providing services that match residents' preferences is an efficiency argument for localists, it can also be used as an equity argument. In jurisdictions with a majority of poor and racial minorities, residents are able to clearly exercise their voice and receive the services they demand most (Ostrom, 1983). For example, in a larger jurisdiction both rich and poor residents could have their tax dollars used for building an opera house while in a smaller jurisdiction populated by poor residents tax dollars can be used for the most essential government services such as courts and police. In times of heightened racial frictions, residents not only care about the types of services they receive, but also about having racially representative public officials (Olson, 1969). Minority populations with minority representation have more positive evaluations of a wide variety of government services both for substantive policy-improvement and symbolic reasons (Marschall and Ruhil, 2007).

The final equity argument for localists is that there are means of achieving equity that do not require consolidation. County, state, and federal programs can target redistribution ${ }^{6}$ to poor areas (Ostrom, 1983). Although there has been an increase in the redistribution responsibilities of local governments, local responses vary with areas of greater fiscal independence and mobile tax sources seeking to limit redistribution (Craw, 2015). There is an optimal level of government for each type of service and existing redistribution programs tend to operate at higher levels of government. Federal government grants ${ }^{7}$ to local and state governments pay for low-income housing, food services, and health care coverage (CBO, 2013). While intergovernmental grants

\footnotetext{
${ }^{6}$ However, redistribution violates the principle of fiscal equivalence by creating a mismatch between those who benefit from a program and those who pay for it (Olson, 1969). The resulting incentives for more government spending make many localists cautious about the efficiency implications of redistribution (Lowery, 2000; Jimenez and Hendrick, 2010).

${ }^{7}$ Federal grants to state and local governments are substantial. In 2011, they accounted for 17 percent of federal outlays and 25 percent of state and local government spending (CBO, 2013).
}

(c) Southern Regional Science Association 2018. 
can finance the unique services that residents in poor jurisdictions demand, special districts covering multiple fragmented local government jurisdictions can provide both rich and poor residents with the same service quality (Parks and Oakerson, 2000). The localists recognize equity concerns but argue that fragmentation actually promotes equity and that redistribution is better conducted by higher levels of government.

\subsection{Spillovers}

Arguably the most active area of debate in recent years between localists and regionalists is over the spillover effects of local public goods. Regionalists argue that with fragmentation, smaller jurisdictions experience greater spillover problems as the costs and benefits of services are not contained within each jurisdiction. Acting in their own self-interest, local government leaders make output level decisions based upon the costs and benefits to their own citizens rather than weighing societal costs and benefits (Williams, 1966). For example, with a positive spillover, there is an underprovision of the public good since the benefits to those outside the jurisdiction are not taken into account. In cases such as air pollution programs where there is a wide distribution of benefits and concentrated costs within the jurisdiction, the public good may simply not be provided at any level (Gustely, 1977). Larger, more consolidated governments help overcome spillover problems by drawing jurisdictional lines coterminous with the area benefitting from the public good (Adams, 1965). With larger jurisdictions, the costs and benefits of services are contained within the region, which results in the socially optimal level of public goods.

Regionalists argue that a wide variety of government services are subject to spillovers. While the list includes such diverse public goods as education, police, recreational facilities, roads, and sewage treatment, each spillover falls into one of two categories (Solé-Ollé, 2006). 'Benefit spillovers' result from public goods produced in one jurisdiction being used in other jurisdictions. Examples include radio and TV broadcasts. 'Crowding spillovers' result from residents of other jurisdictions crowding into the public goods of a jurisdiction. Examples include commuters or visitors crowding recreational facilities such as parks.

Given the current prevailing pattern of urban development, urban sprawl is arguably the most important type of spillover facing local governments. Carruthers (2003) describes the spillover problems of sprawl and how they are exacerbated by political fragmentation. Sprawl occurs as consumers have preferences for single-family housing and automobile ownership. The optimal level of sprawl differs from the actual level since residents do not bear the social costs of congestion, ${ }^{8}$ and therefore, do not pay the full cost of living in a sprawling environment. Political fragmentation exacerbates sprawl since smaller districts have narrower interests that do not internalize congestion in the same manner as larger jurisdictions. Instead of allowing for a variety of land uses, fragmented jurisdictions use exclusionary zoning to maintain low-density, single-family homes that not only contribute to congestion but also reduce efficiency. Lower densities lead to higher service costs as police, road, and sewage systems are spread out to reach even the lowest density areas (Carruthers and Ulfarsson, 2002; Hortas-Rico and Solé-Ollé, 2006). For regionalists, sprawl and other spillover problems are overcome through consolidated governments that provide the socially optimal level of public goods by weighing societal costs and benefits.

\footnotetext{
${ }^{8}$ The pollution that results from sprawl-induced congestion is part of the broader environmental concerns that regional reformers have focused on in recent years (Howell-Moroney, 2008; Kim and Jurey, 2013).
}

(C) Southern Regional Science Association 2018. 
Although larger jurisdictions may reduce spillovers, the localists seek solutions that avoid the problems of consolidation. They argue that spillover problems can be resolved either through local government cooperation or involving higher levels of government in a way that still allows for local government autonomy. Similar to the localists' solution to equity concerns, state or federal grants can be used to compensate local governments. The power to tax and the power to spend can be assigned to different governments. The tax and expenditure assignment problems can be solved by extending authority to varying levels of government in a way that encourages public agents to pursue welfare-maximizing policies (Oates, 1972; 2005). In the case of a positive spillover, jurisdictions providing the service can receive grants that cover the marginal cost of production that is associated with the benefits received by the wider geographic area (Ostrom, 1972). For example, the state government can collect taxes from all residents and compensate school districts that cannot fully internalize all the benefits due to students moving after graduation (Bish and Warren, 1972). Focusing on solutions to specific services is important within the localist tradition because there are different kinds of public goods with different appropriate levels of management (Ostrom, Tiebout, and Warren, 1961; Bish and Warren, 1972). With a unique geographic dispersion of benefits for each public good, different public goods have different levels of spillovers. Thus, a single consolidated government cannot establish jurisdictional boundaries that eliminate spillovers for every service. Rather than consolidate into a single government, spillovers can be dealt with on a case by case basis with special districts. For example, larger special districts such as police can overcome the spillover costs or benefits of having a weak or strong police force (Tiebout, 1956).

Just as the Coase (1960) Theorem suggests that through negotiation individuals can overcome externalities, local governments can negotiate with each other to overcome spillovers (Feiock, 2009). Through cooperation, local governments benefit from economies of scale and sharing the cost of start-up capital (Andrew, 2009). While there are a wide variety of ways for local governments to cooperate ${ }^{9}$, informal agreements are the most common (Walker, 1987). Informal agreements avoid the political $\operatorname{costs}^{10}$ of organization and are fostered through sharing information (Ostrom, Tiebout, and Warren, 1961) and the trust built by repeated interactions with neighboring jurisdictions (Feiock, 2009). Due to their informal nature, negotiations between jurisdictions are able to adjust to the dynamic problems of spillovers (Andrew, 2009). Agreements can be created and dissolved easily, unlike governments which tend to be selfperpetuating. For localists, local government cooperation is an effective way of voluntarily achieving regional governance that overcomes spillover problems.

\subsection{Development}

While efficiency, equity, and spillovers have well-developed theoretical arguments from academic researchers, the development arguments for consolidation stem from regional reformers and regional development plans. Feiock and Carr (1997) summarize the arguments, which can be highlighted by three points. First, consolidation enhances the comprehensive planning capacity of local governments, which can help reduce socially inefficient competition.

\footnotetext{
${ }^{9}$ Walker (1987) details 17 approaches ranging from the politically easiest ways, such as interlocal service agreements, to the politically hardest ways, such as consolidations.

${ }^{10}$ Due to lower political costs, cooperation among local governments is now common. In the 1990s, regionalist reformers recognized that regional governance can be achieved not only through consolidation but also through voluntary cooperation. This recognition sparked the New Regionalism movement (Savitch and Vogel, 2000; Fisken and Norris, 2001; Norris, 2001; Wheeler, 2002). In this view, regionalism and localism are complements rather than substitutes (Parks and Oakerson, 2000).
}

(C) Southern Regional Science Association 2018. 
Second, consolidation simplifies the regulatory and development process, which is generally more efficient within a single jurisdiction. Third, consolidation ensures a large enough resource base for promoting economic development projects.

\section{EVIDENCE}

\subsection{Efficiency}

While the regionalists argue that reducing the costs of bureaucracy is a key efficiency benefit of consolidation, localists warn of the difficulties of reducing bureaucracies and the costs of bureaucratic congestion. Reducing the burden of bureaucracy requires some combination of job and wage cuts. Since neither option is popular within a bureaucracy, as consolidation occurs jobs are saved and wages rise. For example, in both the Athens and Clarke County, Georgia and Wyandotte County and Kansas City, Kansas consolidations, existing bureaucrats added provisions to the consolidation charters ensuring that no public employee would lose their job (Leland and Thurmaier, 2005). In the absence of guaranteed employment codified in consolidation charters, bureaucrats can still use informal means to maintain jobs. During the consolidation of the city of Kawartha Lakes, Ontario, instead of letting bureaucrats go, new positions were created simply to maintain employment (Miljan and Spicer, 2015). Even if consolidation overcomes the incentives of bureaucrats to keep their jobs, wages of government workers tend to be harmonized upwards to the highest pre-consolidation pay scales (Gustely, 1977; Vojnovic, 2000; Reese, 2004; Martin and Schiff, 2011; Miljan and Spicer, 2015). For example, during the consolidation of 21 municipalities in the county of Essex Canada, government workers that had been earning roughly minimum wage in the small rural communities saw their wages rise to the level earned by government workers in urban areas (Miljan and Spicer, 2015). In addition to higher salaries with the same level of employment, larger bureaucracies can also result in higher costs through their increased complexity. After the consolidation of twelve municipal units in the city of Ottawa, government workers in the now larger departments stated that there was "increased red tape for both internal and external users of city services, slower purchasing processes, a backlog in dealing with permits, and a much longer hiring process” (Reese, 2004, p. 600). Costly new technology and retraining are often needed to deal with the greater complexity. In an analysis of five consolidated Canadian municipalities, Vojnovic (2000) finds that four out of five of the municipalities required significant employee retraining and new computers to handle more complex payroll and accounting systems.

Given the large number of local governments and types of regionalization of local governments, there are certainly cases pointing to the efficiency of consolidated governments. For example, Krimmel (1997) compares the consolidated and nonconsolidated police departments of York and Lancaster Counties, Pennsylvania and reports that the consolidated ones have 28 percent lower costs. Other support related to police department consolidation comes from McDavid (2002). He finds that three consolidated police departments in Halifax, Canada managed to reduce expenditures substantially without affecting crime rates. Although these are cases of the efficiency of consolidated governments, they are not in contradiction to the localists' arguments. Since economies of scale vary based upon the service (Ostrom, 1972), maintaining local autonomy while voluntarily consolidating for services with significant economies of scale is consistent with the localist tradition. However, in general, Martin and 
Schiff (2011) find that the literature provides little support for the efficiency arguments of consolidation.

Consolidation has typically not resulted in cost reductions, and from the localists' viewpoint, cost reduction does not even guarantee efficiency because efficiency is also about services matching citizens' preferences. For example, a reduction in costs could be the result of reducing service levels to below what the median voter prefers. The simplest, yet often overlooked, way of evaluating citizens' preferences for consolidation is to examine their popularity. Since 1815 in the U.S., 166 city-county consolidations have been attempted but only 39 have been implemented (Martin and Schiff, 2011). Their unpopularity results from a variety of issues from seemingly trivial problems such as disagreements over the name of the new government (Miljan and Spicer, 2015) to more serious concerns such as higher taxes and wanting to maintain the status quo (Lyons and Scheb, 1998). In their survey of residents of Knox county Tennessee, which experienced four failed city-county consolidation referenda between 1959 and 1996, Lyons and Scheb (1998) find that among voters within the city opposed to consolidation, 25 percent were unsure of why they were opposed. One possible reason for indicating opposition while not being able to express why is the strong belief Americans have had in local government (Norris, 2001). Given that citizens are unlikely to actively support consolidation, using higher levels of government to force consolidation can be an appealing option. Although the legal rights of local governments in the U.S. are strongly established, in Canada provincial governments have more power over local governments. Miljan and Spicer (2015) describe the problems of reducing, often times involuntarily, 850 municipalities in Ontario down to 444 during a five year period. Community groups arose to combat consolidation and remained active in hopes of undoing the consolidation. In areas such as Kawartha Lakes, tax breaks were given to appease the populace, which has resulted in financial stress as long-term debt has increased by 90 percent.

\subsection{Equity}

The first issue with the equity argument is the loss of minority representation. Martin and Schiff (2011) mention that a 2007 study by the Pennsylvania Economy League (PEA) finds that the loss of minority representation has not been an overt problem for city-county consolidations due to the standards set up by the federal Voting Rights Act which ensures legislative rights for minorities. However, based on her research of the consolidation of Louisville and Jefferson County, Kentucky, Clarke (2006) demonstrates that consolidation can cause severe concerns to minorities in the urban core who find their voting power diluted by the addition of suburban populations. In this case, consolidation decreased the voting strength of African Americans in the core city. Swanson's (2000) study of Jacksonville and Duval County, Florida further supports Clarke's (2006) argument since the voting power of African Americans was diluted from 40 percent to 25 percent.

The second concern related to the equity argument is the post-consolidation distribution of taxes and services between urban, suburban, and rural areas. In a case study of the amalgamated Ottawa/Ontario government in Canada, Reese (2004) reports that consolidation was expected to not only enhance equity in the urban area by improving redistribution programs and amenities such as parks, but also increase service in rural areas. However, this comes with a cost of the reduction of service in some affluent suburban areas. Benefits to certain areas come with costs to other areas. Urban residents may feel that they are paying for county-wide services they do not use while rural residents may feel that they are paying for city services they do not 
use. Vojnovic (2000) details the distributional consequences of consolidation between five urban and six rural districts in Canada. Prior to consolidation, tax rates varied based upon service levels with rural areas having lower tax and service levels. After consolidation, tax rates were harmonized so rural areas faced a tax rate increase of up to 80 percent while the increase in service levels remained unclear. Prior to consolidation, poorer residents in rural areas received the basic services they demanded, but post-consolidation they are paying for more services that they do not demand. Blomquist and Parks (1995) analyze the highly-touted Indianapolis Unigov city-county consolidation, which was expected to correct inequality by using suburban property taxes to help finance the city services enjoyed by suburbanites. However, suburban property taxes were used only for county services while those in the city saw tax increases because of having to pay not only for city services but also for county services. In the absence of functioning formal tax-base sharing, implicit tax base sharing can improve equity (Bogart, 2006). For example, taxes on commuter's income is a way of making people who use a city's services share in their costs.

\subsection{Spillovers}

While localists acknowledge the dangers of spillovers, they point to the existence of informal local cooperation to overcome regional problems. In cases of minimal conflict and mutual gains among jurisdictions, interlocal agreements (ILAs) are common. Local governments can pool their resources to take advantage of economies of scale in the provision of services. Miller and Davidson (2015) list 33 specific examples of ILAs in the U.S. including 911 dispatch centers, animal control, law enforcement, and libraries. Leroux and Carr (2010) document 44 local governments in the Detroit metropolitan area that rely extensively on service delivery networks. Through interpersonal networks formed at local professional associations, local government officials collaborate to jointly provide infrastructure, waste disposal, and watershed management. In cases where ILAs break down due to conflicts among jurisdictions, numerous other forms of local cooperation can be implemented. Nunn and Rosentraub (1997) detail how a variety of institutional formats have been used across U.S. cities to solve regional conflicts. In Pittsburgh, Pennsylvania the Alleghany Conference for Community Development (ACCD) has operated as a non-profit corporation fostering regional cooperation since 1944. By utilizing public-private partnerships, it has focused on a variety of regional issues such as air pollution and flood control. Since 1968, the Toledo Metropolitan Area Council of Governments (TMACOG) has served as a voluntary regional council to: “(1) provide a forum for regional governance, (2) facilitate networking for local officials, (3) provide shared information, (4) coordinate issue resolution, (5) plan for regional transportation needs, and (6) plan for regional environmental resources and water quality” (Nunn and Rosentraub, 1997, p. 214). The council has solved a variety of regional issues while still allowing for local government autonomy.

\subsection{Development}

Savitch, Vogel, and Ye (2010) investigate Louisville's ${ }^{11}$ consolidation with Jefferson County, Kentucky in 2003. They find that there has not been any unusual increase in per capita income, employment, or number of business establishments. In reality, the metropolitan areas have remained the same, and the only change is the circle around the city which defines it. This

\footnotetext{
${ }^{11}$ Although studies analyzing the effects of consolidation on development tend to focus on major cities, the issue of consolidation is also faced by smaller cities and regions. For example, West Virginia is considering consolidating its counties from 55 to 30 in order to redevelop the largely rural state through reduced bureaucracy and larger investment projects (Metzner, 2016).
}

(c) Southern Regional Science Association 2018. 
creates a puzzle for why politicians have been so enthusiastic about new consolidations and promoting them locally and nationally. The explanation given in this paper is that politicians and business leaders do not want to admit their mistakes and instead overstate their accomplishments.

Carr, Bae, and Lu (2006) provide another explanation for Louisville’s consolidation with Jefferson County. After the consolidation of the nearby major urban area of Lexington and Fayette County, Kentucky in 1974, local politicians, businesses, and media elites in Louisville and Jefferson County felt pressure and increasing competition from their newly consolidated neighbors. Additionally, they took the growing population and increasing economic competition from Fayette County as an outcome of the consolidation, which contributed to their own consolidation in 2003. However, Carr, Bae, and Lu (2006) point out that there has not been any convincing evidence supporting more economic development caused by the consolidation in either case.

Feiock and Carr (1997) look into the consolidation of the City of Jacksonville and Duval County, Florida in 1968. They argue that although the consolidation might enhance the planning capacity and the legal, jurisdictional, and financial resources of local governments, there has not been any evidence suggesting that the enhanced resources will directly translate into the overall economic development in the consolidated areas. The evidence suggests that the motivation for consolidation is more about individual interests, especially the interests of the elites, rather than economic development.

Based on his study of 195 U.S. cities with populations of more than 100,000 people, Yasuoka (2008) argues that city-county consolidation does not guarantee economic development. He finds that there is no evidence strong enough to support the economic development argument of consolidation, although there is also little evidence to reject it. While city-county consolidations could help relieve the fiscal pressure of cities, the economic development outcome of consolidation is still mixed and ambiguous.

Most recently, Hall, Matti, and Zhou (2017) use the synthetic control method to explore the long-term impact of city-county consolidations on per capita income, population, and employment. The results from the three cases they explore suggest that consolidation does not guarantee development. Contrary to the hopes of development practitioners, across different time horizons and development measures, city-county consolidation is more likely to have negative than positive effects.

While the case study evidence in general suggests that consolidation does not promote economic development, there are specific consolidation efforts that are associated with development. The consolidation of the city of Indianapolis and Marion County into a 'Unigov' is often given as an example of successful development brought about by consolidation. Although urban re-development did occur in Indianapolis after 'Unigov,' it is not clear that consolidation was a causal factor. Private businesses such as the Lilly Corporation aided development by attracting high-income workers while the fastest growing areas of Indianapolis were actually in the suburbs (Rosentraub, 2000). Additionally, the actual amount of consolidation was small with most services remaining decentralized and a reduction in local governments of only 60 to 50 (Blomquist and Parks, 1995).

(C) Southern Regional Science Association 2018. 


\section{CONCLUDING THOUGHTS}

Local governments are an important part of the American system of federalism. However, the last century has seen increasing calls for more regionalism. This paper has outlined the main theoretical arguments for both regionalism and localism while illustrating real-world examples. With efficiency, the case study evidence suggests that although consolidation of certain services, such as police, can increase efficiency, consolidation often decreases efficiency. Wage increases, public employee job protections, and costly transitions make it difficult for consolidation to increase efficiency. With equity, consolidation can dilute minority voting power and exacerbate disputes between city and suburban residents. With spillovers, local governments routinely engage in formal or informal cooperation to overcome regional problems. Lastly, with development, the real-world evidence from city-county consolidations suggests that transitioning to a more regional government does not boost business activity and job growth. The lessons learned in this paper not only inform local governments considering consolidation but also establish a foundation for regional scientists to contribute to the literature.

The consolidation of local governments is a regional issue, and thus, should be of interest to regional scientists. However, research on the regional effects of local governments remains scarce. Given the lack of research in this area, there are numerous directions for subsequent research connecting the study of local and regional governments with key areas in regional science such as migration, policy diffusion, and zoning. Just as Ashby (2007) analyzes the effect of economic freedom on migration flows between U.S. states, subsequent research could explore migration patterns across counties or states with varying levels of local government consolidation. Following Burge and Rogers (2016) who explore the diffusion of local tax policy across municipalities, subsequent research could examine how the structure of local governments influences policy diffusion. Additionally, studying whether the structure of local government itself is shaped by policy diffusion is an open area of research. With zoning, subsequent research could follow Ross and Carley (2016) by exploring how the regionalization of local governments affects the location of nuisance activities. There is a large literature within the fields of public economics and public administration on the consolidation of local governments that has not been utilized in regional science. Given the regional nature of local governments, subsequent research in regional science can fill this gap.

\section{REFERENCES}

Adams, Robert F. (1965) “On the Variation in the Consumption of Public Services,” Review of Economics and Statistics, 47, 400-405.

Andrew, Simon A. (2009) "Recent Developments in the Study of Interjurisdictional Agreements: An Overview and Assessment,” State \& Local Government Review, 41, 133-142.

Ashby, Nathan J. (2007) "Economic Freedom and Migration Flows between US States," Southern Economic Journal, 73, 677-697.

Berry, Christopher. (2008) "Piling on: Multilevel Government and the Fiscal Common - Pool," American Journal of Political Science, 52, 802-820.

Besley, Timothy and Anne Case. (1995) “Incumbent Behavior: Vote Seeking, Tax Setting and Yardstick Competition,” American Economic Review, 85, 25-45.

(C) Southern Regional Science Association 2018. 
Bish, Robert L. and Robert Warren. (1972) "Scale and Monopoly Problems in Urban Government Services,” Urban Affairs Review, 8, 97-122.

Blomquist, William and Roger B. Parks. (1995) "Fiscal, Service, and Political Impacts of Indianapolis-Marion County’s Unigov,” Publius: The Journal of Federalism, 25, 37-54.

Bogart, William T. (2006) Don't Call It Sprawl. Cambridge University Press: Cambridge, Massachusetts.

Boyne, George A. (1992) "Local Government Structure and Performance: Lessons from America?,” Public Administration, 70, 333-357.

. (1997) "Public Choice Theory and Local Government Structure: An Evaluation of Reorganisation in Scotland and Wales,” Local Government Studies, 23, 56-72.

Brennan, Geoffrey and James M. Buchanan. (1980) The Power to Tax: Analytic Foundations of a Fiscal Constitution. Cambridge University Press: Cambridge, Massachusetts.

Burge, Gregory S. and Cynthia L. Rogers. (2016) "Leaders, Followers, and Asymmetric Local Tax Policy Diffusion,” Journal of Regional Science, 56, 313-331.

Carr, Jered B., Sang-Seok Bae, and Wenjue Lu. (2006) "City-County Government and Promises of Economic Development: A Tale of Two Cities," State and Local Government Review, 38, 131-141.

Carruthers, John I. (2003) "Growth at the Fringe: The Influence of Political Fragmentation in United States Metropolitan Areas,” Papers in Regional Science, 82, 475-499.

Carruthers, John I. and Gudmundur F. Ulfarsson. (2002) "Fragmentation and Sprawl: Evidence from Interregional Analysis,” Growth and Change, 33, 312-340.

Campbell, Rebecca J. (2004) "Leviathan and Fiscal Illusion in Local Government Overlapping Jurisdictions,” Public Choice, 120, 301-329.

Coase, Ronald H. (1960) “The Problem of Social Cost,” Journal of Law and Economics, 3, 1-44.

Congressional Budget Office. (2013) Federal Grants to State and Local Governments. Government Printing Office: Washington, DC.

Craver, Kevin P. (2016) "Local Governments, Voters Should Have Power to Consolidate Illinois Local Governments, Report Says,” Northwest Herald, Available online in May 2017 at http://www.nwherald.com/2016/01/04/local-governments-voters-should-have-power-toconsolidate-illinois-local-governments-report-says/arm07ie/.

Craw, Michael. (2015) "Caught at the Bottom? Redistribution and Local Government in an Era of Devolution,” State and Local Government Review, 47, 68-77.

Eberts, Randall W. and Timothy J. Gronberg. (1988) "Can Competition Among Local Governments Constrain Government Spending?,” Economic Review, 24, 2-9.

Feiock, Richard C. (2009) "Metropolitan Governance and Institutional Collective Action," Urban Affairs Review, 44, 356-377.

Frisken, Frances and Donald F. Norris. (2001) “Regionalism Reconsidered,” Journal of Urban Affairs, 23, 467-478. 
Giertz, J. Fred. (1981) “Centralization and Government Budget Size,” Publius: The Journal of Federalism, 11, 119-128.

Grosskopf, Shawna and Suthathip Yaisawarng. (1990) "Economies of Scope in the Provision of Local Public Services,” National Tax Journal, 43, 61-74.

Gustely, Richard D. (1977) “The Allocational and Distributional Impacts of Governmental Consolidation: The Dade County Experience,” Urban Affairs Review, 12, 349-364.

Hall, Joshua C. (2006) "Fiscal Competition and Tax Instrument Choice: The Role of Income Inequality,” Economics Bulletin, 8, 1-8.

. (2015) "Local Government Border Congruence and the Fiscal Commons: Evidence from Ohio School Districts,” Journal of Regional Analysis \& Policy, 45, 141.

. (2017) “Does School District and Municipality Border Congruence Matter?,” Urban Studies, 54, 1601-1618.

Hall, Joshua C. and Justin M. Ross. (2010) “Tiebout Competition, Yardstick Competition, and Tax Instrument Choice: Evidence from Ohio School Districts,” Public Finance Review, 38, 710-737.

Hall, Joshua C., Josh Matti, and Yang Zhou. (2017) "The Economic Impact of City-County Consolidations: A Synthetic Control Approach,” West Virginia University Working Paper No. 17-08, Department of Economics: West Virginia University.

Hill, Richard Child. (1974) "Separate and Unequal: Governmental Inequality in the Metropolis," American Political Science Review, 68, 1557-1568.

Hirschman, Albert O. (1970) Exit, Voice, and Loyalty. Harvard University Press: Cambridge, Massachusetts.

Hortas-Rico, Miriam and Albert Solé-Ollé. (2010) "Does Urban Sprawl Increase the Costs of Providing Local Public Services? Evidence from Spanish Municipalities,” Urban Studies, 47, 1513-1540.

Howell-Moroney, Michael. (2008) “The Tiebout Hypothesis 50 Years Later: Lessons and Lingering Challenges for Metropolitan Governance in the 21st Century," Public Administration Review, 68, 97-109.

Jimenez, Benedict S. (2014) "Separate, Unequal, and Ignored? Interjurisdictional Competition and the Budgetary Choices of Poor and Affluent Municipalities,” Public Administration Review, 74, 246-257.

Jimenez, Benedict S. and Rebecca Hendrick. (2010) "Is Government Consolidation the Answer?,” State and Local Government Review, 42, 258-270.

Kim, Jae Hong and Nathan Jurey. (2013) "Local and Regional Governance Structures Fiscal, Economic, Equity, and Environmental Outcomes,” Journal of Planning Literature, 28, 111-123.

Leland, Suzanne and Kurt Thurmaier. (2005) "When Efficiency is Unbelievable: Normative Lessons from 30 Years of City-County Consolidations," Public Administration Review, 65, 475-489. 
LeRoux, Kelly and Jered B. Carr. (2010) "Prospects for Centralizing Services in an Urban County: Evidence from Eight Self-Organized Networks of Local Public Services," Journal of Urban Affairs, 32, 449-470.

Lowery, David. (2000) “A Transactions Costs Model of Metropolitan Governance: Allocation Versus Redistribution in Urban America,” Journal of Public Administration Research and Theory, 10, 49-78.

Lyons, William and John M. Scheb. (1998) “Saying 'No' One More Time: The Rejection of Consolidated Government in Knox County, Tennessee," State and Local Government Review, 30, 92-105.

Marschall, Melissa J. and Anirudh VS Ruhil. (2007) “Substantive Symbols: The Attitudinal Dimension of Black Political Incorporation in Local Government,” American Journal of Political Science, 51, 17-33.

Martin, Lawrence L. and Jeannie Hock Schiff. (2011) "City-County Consolidations: Promise versus Performance,” State and Local Government Review, 43, 167-177.

Maxey, Chester C. (1922) “The Political Integration of Metropolitan Communities,” National Municipal Review, 11, 229-254.

McKean, Roland N. (1964) "Divergences between Individual and Total Costs within Government,” American Economic Review, 54, 243-249.

Metzner, Janet. (2016) “WVU Studying Government Consolidation,” The Weirton Daily Times, Available online in May 2017 at http://www.weirtondailytimes.com/news/localnews/2016/10/wvu-studying-government-consolidation/.

Miljan, Lydia and Zachary Spicer. (2015) Municipal Amalgamation in Ontario. Fraser Institute: Vancouver, BC, Canada.

Miller, Wayne P. and Abby Davidson. (2015) Interlocal Agreements. Arkansas Public Policy Center: Little Rock, Arkansas.

Moe, Terry M. (2006) "Political Control and the Power of the Agent," Journal of Law, Economics, and Organization, 22, 1-29.

Niskanen, William A. (1975) “Bureaucrats and Politicians,” Journal of Law and Economics, 18, 617-643.

Norris, Donald F. (2001) "Prospects for Regional Governance under the New Regionalism: Economic Imperatives versus Political Impediments,” Journal of Urban Affairs, 23, 557571.

Nunn, Samuel and Mark S. Rosentraub. (1997) “Dimensions of Interjurisdictional Cooperation,” Journal of the American Planning Association, 63, 205-219.

Oates, Wallace E. (1972) Fiscal Federalism. Harcourt Brace Jovanovich: New York, New York. . (2005) “Toward a Second-Generation Theory of Fiscal Federalism,” International Tax and Public Finance, 12, 349-373.

Olson, Mancur. (1969) “The Principle of 'Fiscal Equivalence': The Division of Responsibilities among Different Levels of Government,” American Economic Review, 59, 479-487. 
Ostrom, Elinor. (1972) "Metropolitan Reform: Propositions Derived from Two Traditions," Social Science Quarterly, 53, 474-493.

(1983) “The Social Stratification-Government Inequality Thesis Explored," Urban Affairs Review, 19, 91-112.

Ostrom, Vincent, Charles M. Tiebout, and Robert Warren. (1961) "The Organization of Government in Metropolitan Areas: A Theoretical Inquiry,” American Political Science Review, 55, 831-842.

Parks, Roger B. and Ronald J. Oakerson. (2000) "Regionalism, Localism, and Metropolitan Governance: Suggestions from the Research Program on Local Public Economies,” State and Local Government Review, 32, 169-179.

Pennsylvania Economy League (PEA). (2007) A Comparative Analysis of City/County Consolidations. Pennsylvania Economy League of Southwestern Pennsylvania: Pittsburgh, Pennsylvania.

Reese, Laura A. (2004) "Same Governance, Different Day: Does Metropolitan Reorganization Make a Difference?,” Review of Policy Research, 21, 595-611.

Rosentraub, Mark S. (2000) "City-County Consolidation and the Rebuilding of Image: The Fiscal Lessons from Indianapolis's UniGov Program,” State and Local Government Review, 32, 180-191.

Ross, Justin M. and Sanya Carley. (2016) "Do Local Governments Site Nuisance Activities Along Borders? An Empirical Strategy Applied to Wind Turbines,” SSRN Electronic Journal Working Paper, SSRN.

Salmon, Pierre. (1987) “Decentralisation as An Incentive Scheme,” Oxford Review of Economic Policy, 3, 24-43.

Samuelson, Paul A. (1954) “The Pure Theory of Public Expenditure,” Review of Economics and Statistics, 36, 387-389.

Savitch, Hank V. and Ronald K. Vogel. (2000) “Introduction: Paths to New Regionalism,” State and Local Government Review, 32, 158-168.

Savitch, Hank V., Ronald K. Vogel, and Lin Ye. (2010) "Beyond the Rhetoric: Lessons from Louisville’s Consolidation,” American Review of Public Administration, 40, 3-28.

Solé-Ollé, Albert. (2006) "Expenditure Spillovers and Fiscal Interactions: Empirical Evidence from Local Governments in Spain,” Journal of Urban Economics, 59, 32-53.

Tiebout, Charles M. (1956) “A Pure Theory of Local Expenditures,” Journal of Political Economy, 64, 416-424.

Turnbull, Geoffrey K. and Salpie S. Djoundourian. (1993) “Overlapping Jurisdictions: Substitutes or Complements?,” Public Choice, 75, 231-245.

Vojnovic, Igor. (2000) “The Transitional Impacts of Municipal Consolidations,” Journal of Urban Affairs, 22, 385-417.

Walker, David B. (1987) "Snow White and the 17 Dwarfs: From Metro Cooperation to Governance,” National Civic Review, 76, 14-28. 
Wheeler, Stephen M. (2002) "The New Regionalism: Key Characteristics of An Emerging Movement,” Journal of the American Planning Association, 68, 267-278.

Williams, Alan. (1966) "The Optimal Provision of Public Goods in a System of Local Government,” Journal of Political Economy, 74, 18-33.

Williams, Oliver P. (1967) "Life Style Values and Political Decentralization in Metropolitan Areas,” Southwestern Social Science Quarterly, 48, 299-310.

Yasuoka, Masaharu. (2008) “City-County Separation and Consolidation in the United States: The Impact on Urban Growth,” Japanese Journal of American Studies, 19, 117-196.

Yeung, Ryan. (2009) "The Effects of Fiscal Decentralization on the Size of Government: A Meta - Analysis,” Public Budgeting \& Finance, 29, 1-23.

Zax, Jeffrey S. (1989) “Is There A Leviathan in Your Neighborhood?,” American Economic Review, 79, 560-567.

Zimmerman, Joseph F. (1970) "Metropolitan Reform in the US: An Overview," Public Administration Review, 30, 531-543.

(c) Southern Regional Science Association 2018. 